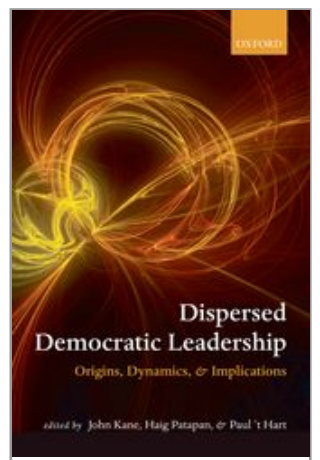

Dispersed Democratic Leadership: Origins, Dynamics, and Implications

John Kane, Haig Patapan, and Paul 't Hart

Print publication date: 2009

Print ISBN-13: 9780199562992

Published to Oxford Scholarship Online: October 2011

DOI: 10.1093/acprof:oso/9780199562992.001.0001

\title{
Dispersed Democratic Leadership Revisited
}

\author{
John Kane \\ Haig Patapan \\ Paul't Hart
}

DOI:10.1093/acprof:oso/9780199562992.003.0016

\begin{abstract}
Keywords
This book began by observing that most democratic theorists have difficulty in articulating a proper role for leadership, largely because none among democratic equals has any innate or inherent right to rule over others. Democracy requires good leadership if it is to function effectively, yet the very idea of leadership seems to conflict with democracy's egalitarian ethos. In practice, democracy's tendency is not to eliminate leadership but to multiply it and disperse it throughout society to a rather extraordinary degree. There are many unique opportunities - as well as constraints - that leaders confront in negotiating the demands of their specific offices within the larger expectations of a democratic regime. This chapter reflects on these contributions and their implications.
\end{abstract}

\footnotetext{
Keywords: dispersed leadership, democracy, popular sovereignty, liberal constitutionalism, monarchy, bureaucracy, civic leadership, democratization
}

We began this study by observing that most democratic theorists have difficulty in articulating a proper role for leadership, largely because none among democratic equals has any innate or inherent right to rule over others. Democracy requires good leadership if it is to function effectively, yet the very idea of leadership seems to conflict with democracy's egalitarian ethos. The more democratic leaders lead from the front, the less democratic they appear; the more they act like good democrats, the less they seem like true leaders. Confronted with this dilemma, the general tendency among scholars has been to 
accept the need for leadership in practice while overlooking it in theory and consequently failing to offer a yardstick for assessing leadership within democracy (Ruscio 2004; Wren 2007; Kane and Patapan 2008). Meanwhile many explore paths towards wider participation and deliberation in search of a social consensus that would arguably make democracy 'more democratic' (Barber 1984; Cohen 1989; Dryzek 1990; Benhabib 1996; Lijphart 1999; Gutman and Thompson 2004). However, none of them articulate a clear role for leadership. Indeed their unexpressed aim often seems to be to eliminate the need for leadership altogether.

Leadership cannot, however, be eliminated, at least not without endangering the polity. This volume shows that in practice democracy's tendency is not to eliminate leadership but to multiply it and disperse it throughout society to a rather extraordinary degree. The volume's chapters have uncovered the unique opportunities - as well as constraints - that a variety of leaders confront in negotiating the demands of their specific offices within the larger expectations of a democratic regime. Here we reflect on these contributions and their implications. Our discussion is in four parts. First we trace the effects of the two main drivers of leadership dispersal in democracy: popular sovereignty and liberal constitutionalism. We then explore the implications of leadership dispersal, particularly the need to understand and manage the often sensitive relations between various (p.300) loci (e.g. heads of government, top officials, international organizations, and non-profit leaders) and the various forms (e.g. political, administrative, judicial, and civic, as discerned in Table 1.1) of public leadership in democratic systems. We will see, for example, that some leadership offices (and their holders) have a tendency to resist the realities of distributed leadership that democratic dispersal imposes upon them by attempts to centralize power resources, demarcate and enlarge professional autonomy, and expand their authority while trying to diminish that of others. Third, we discuss various normative criteria for assessing the effects, beneficial and otherwise, of leadership dispersal, and note the importance of sustaining a subtle balance between them all. Finally, we suggest three avenues for future research on the nature of leadership in democracy that follow on from the dispersal perspective developed in this volume.

\section{Leadership dispersal}

As we noted in the introduction and have seen reinforced in many of the chapters, the dispersal of leadership in modern democracies has two seminal sources. One is the doctrine of popular sovereignty whose egalitarian premises allow potentially anyone an influential voice in public affairs. The other is the liberal constitutional division of powers designed to moderate and control authority in the modern state. Let us revisit both. 
The impulse from popular sovereignty

In addressing the first of these, it is important to note that much of the dispersal that has occurred under this impulse has been in the nature of an historical achievement, usually the result of long political struggle. Most Western liberal democracies grew out of monarchical and patriarchal systems in which individuals ruled with, at most, only partial express consent of the governed. As the moral and political authority of monarchical systems declined, an increasing number of popular voices clamoured to be heard. Monarchs for their part were increasingly compelled to listen and, in listening, to cede authority, as noted long ago by Antoine de Rivarol: 'From the day when the monarch consults his subjects, sovereignty is as though suspended...When people cease to esteem, they cease to obey. A general rule: peoples whom the king consults begin with vows and end with wills of their own' (cited in Godechot 1981: 33; see also Elzinga, this volume). The democratic thrust of Western history has been, through many trials and upheavals, to release a multitude of individual wills from the thrall of traditional authority while yet contriving to assemble them into the collective will necessary for effective government. Those who have sought to exercise leadership in this new and difficult political domain have had to learn to cope with an increasing number of wills that can no (p.301) longer be simply commanded or ignored, even while they fend off rivals from an ever-expanding pool of contenders for office.

That the struggle towards equality continues today for hitherto overlooked or actively discouraged social groups is shown in Sykes' chapter on women ministers, which can be read as emblematic of many other possible examples: Catholic, African American, and Latino penetration of US high public offices; Magreb, Turkish, and Moroccan immigrant representation in top public positions in France, Germany, and Holland, respectively; lower caste penetration of the Indian corridors of power; indigenous office-holding in Latin America, Canada, Australia, and New Zealand. All these could provide stories of slow numerical growth over time in the face of entrenched bias, institutional stickiness and elite attempts to marginalize, co-opt, and normalize would-be leaders from 'out-groups' (De Zwart 1994). Incidental cases of success (e.g. Thatcher, Meir, Gandhi, and Clarke among women; Obama the most recent conspicuous breakthrough in the United States' racial divide) serve to remind us how far democracy's dispersal, not just of leadership roles, but of the opportunities to fill them has yet to go.

Nevertheless, the process of dispersal continues, sometimes denoted these days as the 'displacement of politics', or the 'hollowing out' of the state, or the 'fragmentation' of governance (Bovens, Derksen, Witteveen, Becker, and Kalma 1995; Frissen 1999). The tendency throughout has been to expand the field, not only of who gets to be a leader but, by virtue of the very clamour of competing voices, the loci of leadership in society. Dispersion gives unprecedented and in some instances unexpected authority to a large and growing number of offices 
that are often contingent on, yet distinct from, conventional political offices. The chapters by Schudson, Bell, and Schmid, for example, discuss the importance of leaders in the media, business, and other non-governmental fields in influencing politics and policy. Nor is dispersal confined to the domestic arena, as demonstrated by Verbeek's chapter on the post-Second World War rise of international regimes and the international organizations dedicated to making them work. These have created a whole new set of public offices offering leadership possibilities to Inter-Governmental Organization (IGO) executives adept at operating in the multi-level governance settings thus created. This proliferation, remarkably, affects even authoritarian regimes that choose, for appearances' sake, to dress themselves up as democracies - tolerating a semiindependent judiciary as proof of the alleged adherence to the rule of law, building a façade of parliamentarism, and affording some measure of freedom of speech. In thus tolerating diluted forms of opposition and oversight, they occasionally produce genuinely competing centres of leadership (Kane and Patapan 2008).

The democratic dispersal of leadership has been hugely assisted by advances in technology, particularly technologies that radically improve ability to communicate, persuade, and monitor at ever-increasing speed. From Gutenberg (p.302) to Google, each wave of communication technology has widened the public sphere and enabled more people and groups to perform public leadership roles. Perhaps the most entertaining example of this trend is the rise of celebrity leadership, as discussed here by 't Hart and Tindall. Here the public activism of 'stars' is immeasurably helped by their ability to capture huge audiences on all mediums of communication, often right across the globe. In fact, much of the high public profile and indeed public leadership of former government leaders rests on them achieving a similar kind of 'celebrity' status, and some of them have practically become one-man brands (Needham 2005). As we see in Keane's chapter, they can cleverly exploit the multitude of contemporary communication channels at their disposal to stake out new leadership roles for themselves even after leaving office. The Bonos and Mandelas of the world can thus draw on, and exploit, one another's distinct public auras to advance their own particular civic leadership ambitions.

At the same time, new technology has placed a burden of adaptation on conventional leaders in existing institutions. Erwin Hargrove's trend survey of British and US heads of government clearly suggests that over time politicians have had to command an ever-widening range of communication skills. Indeed, leaders and would-be leaders ignore the ever-transforming carriers of communication at their peril. During the 2008 presidential campaign in the United States it proved damaging, for instance, for the Republican candidate John McCain to admit he did not do emails or even know how to operate a 
computer, when his much younger rival was using state-of-the-art Web and mobile phone technology to engineer an upset in the presidential primaries.

Clearly, the relative importance of mass (as opposed to inter-elite) communication as a sine qua non for acquiring political authority has increased exponentially. At the same time, the diversity of communication channels has burgeoned: FDR could focus on a few key set piece speeches and casual 'fireside' radio chats; Obama (aided by a massive and highly skilled communications staff) had to cover many more bases. The latter's successful use of SMS-texting during the 2008 presidential campaign revealed the shape of things to come. Everywhere now, Web-based communication allows wellequipped political elites to 'cut out the middleman' (e.g. journalists and television stations) in communicating with mass constituencies.

Just as importantly, the very character of public communication has changed. From the age of the printing press to that of television, new channels of communication have tended to simply provide ever more powerful 'bullhorns' amplifying leader message to audiences. But this requires leaders who really understand the possibilities. Australian Prime Minister John Howard looked hopelessly out of touch when on the cusp of his bid to win a fifth consecutive election he began his inaugural YouTube message by saying 'Good Morning' to what he imagined must have been the people viewing his message 'live' (Cunningham 2008). The recent explosion in interactive forms (p.303) of communication has changed the nature of the leadership game much more widely, however. It has lowered the threshold of skills and resources required from those who seek to play it. In fact, many people typically confined to audience roles in twentieth-century democracies can now realistically aspire to play leadership roles on at least some public issues some of the time - if they are Web-literate. Some even get to play the role by accident (see Schudson's story about Farnaz Fassihi's email from Baghdad). This fragmentation of the public sphere has challenged political parties, interest groups, social movements, administrative agencies, and news organizations alike.

Schudson suggests that the fast-increasing transformation of the civic information function in and indeed across contemporary democracies means that leaders of conventional news organizations like the New York Times or major television networks face significant challenges relating to their mission, technologies, and market share. The once unshakeable hold of 'the press' on 'the public', and thus the great dependency of political leaders on political journalists, is fading fast. Nor is it just journalists and news organizations that are thus challenged; all agents and loci of political, civic, administrative, and judicial leadership must now reinvent their modus operandi. Those that do stand to gain exposure, credibility, and clout; those that do not, risk irrelevance and indeed oblivion. 
The impulse from liberal constitutionalism

Clearly some of the key manifestations of dispersed leadership covered in this volume are the product of deliberate and often long-contested efforts to build a system of checks and balances around early monocratic rulers or colonizers. Absolute monarchies were tamed by certain key fruits of liberal political thought: the rule of law; the rise of parliamentarism; and the constitutional protection of freedom of speech that permitted the press and the academy to flourish. Institutional designs founded upon liberal conceptions of individual rights and freedoms account for the familiar political offices secured by liberal constitutionalism and the separation of powers - parliament, the executive, and the judiciary. The chapters in this volume addressing the role of the executive, the opposition, and the judiciary in effect explore this liberal democratic aspect of dispersal. In each, however, we also discern the perennial tendency of each office to broaden the scope of its authority, thus creating tensions between the offices and imposing considerable 'diplomatic' demands on the respective officeholders. These are perhaps the best-known examples of dispersal of leadership and, as such, the focus of extensive scholarship and debate.

Dispersed leadership of the checks and balances variety trades off the shortterm decisiveness of monocratic rule against the benefits of more timeconsuming, piecemeal, and at times 'messy' processes of a system with (p.304) multiple institutional veto players at its core. (Its logic also dictates a preference for federal above unitary systems, and within unitary systems for maximal autonomy for lower levels of government.) The diffusion of sites at which agenda-setting, public policy-making, and public service delivery occur (roughly the political and administrative leadership functions) we might call the 'first face' of leadership dispersal. A 'second face' comprises rapidly multiplying sites concerned with vetting and opposing political and administrative officeholders (the dispersal of 'watchdog' forms of public leadership).

Taken altogether these sites constitute what John Uhr calls a 'lattice of leadership', a set of public offices and roles that can each claim a certain amount of public legitimacy for their holders to engage in leadership activities. In effect this has created a 'mutually supportive arrangement of diversified leadership, consistent with the constitutional principles we associate with separation of powers doctrines' (Uhr 2008: 41). In every contemporary democracy this trajectory of leadership dispersal has been far advanced, although its nuances and institutional manifestations may differ and may be subject to periodic expansion or revision (e.g. New Zealand's switch to an electoral system of proportional representation, or the European Union's continuing attempts to broaden, deepen, and democratize its governance arrangements).

Both democratic thought and liberal democratic institutional design foster the idea that public power is at once a precious and a dangerous resource, best divided across different institutions and office-holders. With power dispersed 
and the wielders of that power forced to bargain with one another, be accountable to one another, and to deliberate together before collective action is possible, democratic societies are arguably governed in less intimidating, more predictable, and smarter ways. As noted above, this is an historically evolving process. But there is strong evidence to suggest that, slowly but surely, even the strongest bulwarks of hierarchy, patriarchy, and 'government knows best' mentality are having to come to terms with the realities of 'shared power' in contemporary, globalized 'network societies' (Crosby and Bryson 2005; Morse and Buss 2007). The world over, governments and bureaucracies are trying to reshape themselves to accommodate more participative, deliberative ways of engaging with citizens (OECD 2008). They try to seduce other public and private actors into horizontal (as opposed to top-down) forms of coordinated, collaborative, networked governance (Rhodes 1997; Goldsmith and Eggers 2004; Koppenjan and Klijn 2004; Agranoff 2007). And they attempt to absorb the large and increased demands for transparency and public accountability imposed upon them. Even within the judiciary, many a 'strategy session' is devoted to how the institution and its officers can continue to project authority in the face of less automatic deference and more intense public scrutiny (Huls, Adams, and Bomhoff 2009).

The more democratic ideas take root in constitutional and institutional practices, the greater the number and diversity of public leadership loci likely (p.305) to be found within the political system. In established democracies, leadership dispersal becomes its own cause: we like the idea of it, we feel it 'works', and so we create more of it.

Responses to dispersed leadership

The democratic tendency to disperse offices explored above would appear to have no obvious limits. Yet the very strength of such a drive may conceal equally powerful countervailing influences that resist such diffusion of leadership. Some of these countervailing forces have their origin in principles that may challenge, or contend with, the notion of democracy itself. For example, the idea of the 'knower' or the 'expert' questions the very premise of popular sovereignty: authority should be vested in those who know, rather than in the many (Willard 1996). Thus the notion of the 'expert' becomes a principled basis for resisting the dispersion of leadership and authority. Similar principles include the idea of efficiency, of the rule of law, and inviolable principles, such as individual dignity or rights. In addition to these principles, however, we contend that there is a countervailing dynamic in the very notion of 'office' itself. Hence dispersion inevitably fosters attempts by the new office-holder to retain such authority, and thereby resist the movement towards greater democratic dispersion. Often such resistance will be articulated in terms of principles - for example, as we will see, bureaucracy will claim that it should retain its authority because of its superiority in knowledge and expertise. Nevertheless, the persistent evidence of the resistance to dispersal is found in struggles over control of political agendas 
and policies, and will generally involve leaders in some sites trying to maintain their independence against assaults upon it by leaders in another, usually those in the elected branch. The range and complexity of this dynamic of dispersal and resistance means that we can only indicate some of the important ways dispersal of office is countered in democracies. Our selection is intended to show the diversity in the nature of offices and thereby the complexity of the dynamic of dispersal and resistance.

The monarchy

There are some offices that seem, by their very nature, to resist democratic dispersal. Foremost among them is that most pre-eminently undemocratic of institutions, the monarchy, which by definition implies concentrated authority. This may seem of little consequence given that constitutionalized monarchs have purely ceremonial duties and a merely 'dignified' role (Bagehot 1873). Yet as Elzinga argues the matter is not so simple, and that the monarchy continues to play an important 'neutral' role essential for the smooth functioning of modern democracies.

(p.306) Elzinga shows that contemporary kings and queens must be exceptionally circumspect in navigating their particular political leadership dilemma. Their formal powers - including the power to speak out - are usually extremely limited, so they have to rely on tradition-based, symbol-driven public affection as their only fount of authority, a shaky resource in rapidly modernizing and postmodernizing societies. Nevertheless, as 'managers of last resort' during acute crises of the democratic polity - for example, during periods of sustained political paralysis, unrest, or coup attempts - monarchs like Juan Carlos of Spain, Albert of Belgium, Bhumbol of Thailand and Gyanendra of Nepal have had to make tough judgement calls. The choices of these monarchs did not just affect the immediate course and outcomes of the crises at hand, they also proved fateful in either solidifying (Juan Carlos) or fatally undermining (Gyanendra) their own leadership and indeed the future of their monarchies. Not touched upon by Elzinga, but equally significant from a dispersed leadership perspective, is the reverse situation, when crises of the monarchy compromise its moral authority or constitutional integrity. In those circumstances - the Lockheed bribery scandal involving Dutch Queen Juliana's husband Prince Bernhard, the Charles and Diana scandal in the United Kingdom, and the crisis over Diana's death - political and sometimes judicial leaders are faced with fateful judgement calls on whether and how to help the monarch, and thereby the monarchy, save face. If Elzinga is right, then the constitutionalized monarchy should be seen as a prime example of the democratic dispersal dynamic - an office that serves and respects the democracy precisely when it resists through 'neutral' adjudication. Democracies have paradoxically created a new, predominantly symbolic and moral leadership niche for the very monarchs they first helped strip of their active powers of authoritarian rule. 
The executive

Much more seriously resistant to leadership dispersal is the democratic office which inherits most of the prerogatives and functions formerly reserved for monarchs, the political executive. Indeed the executive arm of government seems to harbour an enduring impulse to amass institutional power unto itself. There has been much critical discussion, for example, of the increasing 'presidentialization' of the prime ministership in parliamentary systems. The accuracy of this label has been questioned, as has the geographical extent of the phenomenon (see chapters by Hargrove and Sykes; Rhodes 2007), but certain features have been observed in many Westminster systems: the steady growth of prime ministerial staff to form a 'shadow bureaucracy'; the personalization of the government by prime ministerial dominance of public communication; and the increasing prevalence of prime minister-dominated 'short cuts' to full cabinet deliberation and collective responsibility (Foley 1993, 2000; Poguntke and Webb 2005; Walter and Strangio 2007).

(p.307) In the United States, meanwhile, there has been fierce debate about the tendency towards the formation of an 'administrative' or even 'imperial' presidency (Nathan 1983; Schlesinger 2004). The George W. Bush administration's rather blunt attempts to endow a 'unitary executive' with quasimonarchical prerogatives by putting it beyond ordinary legal controls has deepened the bitterness of this debate. Hargrove argues that attempts at presidential rule by executive order rather than legislative negotiation with Congress are predominantly a Republican phenomenon - and indeed the early period of the Obama presidency has seen fewer examples of outright presidential imposition and a return to persuasion and bargaining.

Nevertheless, such attempts to (re)assert executive dominance should not be written off as mere renegade, ultimately futile efforts to turn back the clock. They are rather a symptom of, and response to, the inherent difficulties of democratic leadership. The tendency to dispersal grows out of a permanent licence of members of the sovereign body, the people, to dissent. The consequence of this is the multiplication of loci where dissent can be made effective in questioning, obstructing, or countermanding the actions of a government that will, nonetheless, be held strictly responsible for its failures to act. The desire of executives with a heavy burden of responsibilities would seem quite naturally to lean towards gathering more securely into their own hands the reins of effectual power. Such attempts will, just as naturally in democracies, sooner or later be effectively resisted. There is no a priori reason, moreover, why continued dispersal in some domains - judicial or civic, say - may not coexist with robust trends towards centralization in another - for instance, the political executive. The tug of war between dispersing and centralizing tendencies should therefore be regarded as a permanent feature of liberal democratic government. It is a manifestation of the always inconclusive trade-off between principles of 
efficiency and democratic inclusion, and between principles of efficiency and liberty.

The bureaucracy

Modern bureaucracies provide unique insights into the dynamic of democratic leadership dispersal and resistance. Bureaucratic leaders (administrators at the highest echelons of the civil service) necessarily perform a delicate balancing act between the twin imperatives of maximizing their organizations' responsiveness (to political masters, clients, and partners) and safeguarding their own professional autonomy and integrity. But if the balance appears to slide too far towards autonomy, their organization risks appearing as an independent centre of power challenging the authority of the elected government. In recent years, this drama played out in a series of administrative reforms with interesting consequences for our story of dispersal versus concentration of leadership.

(p.308) Wise administrators will not, of course, bite the hand that supplies their organization with its lifeblood - mandate, money, tasks, and legislative support. But professionalism and expertise nevertheless always allow a measure of independence and some capacity for resistance. With distinctive missions, sophisticated professional technologies and tight-knit stakeholder coalitions, established bureaucratic institutions can wield a licence for recalcitrance visàvis governments, central agencies, and watchdogs of various kinds. They may feel secure enough to voice concerns to political principals and to appear frontof-stage in democratic deliberations - to act, in other words, as 'public entrepreneurs' (Lewis 1980; Boin and Goodin 2007). Nevertheless, as Kane and Patapan argue, the risk that democratically elected leaders would come to resent and wish to tame the power of a professional bureaucracy capable of opposing their will is always a real prospect. Throughout the late twentieth century, governments around the world conceived the need to regain political control of administrations that had allegedly become laws-unto-them-selves. This was done, importantly, by dismantling the main locus of the old bureaucratic leadership at the most senior levels of the service. Lifetime career bureaucrats, who had always performed a crucial gatekeeping and thus leadership role in policy processes, were replaced by executives on time-fixed performance contracts that made them theoretically more amenable to political direction.

This greater responsiveness was argued to be necessary to achieve greater efficiency and effectiveness in public service than the old bureaucracy, for all its declared professionalism, seemed capable of delivering. Certainly it was undeniable that administrators faced a daunting task in trying to induce the massive machinery of government successfully to implement political choices and deliver services. Zealous reformers argued that the task required, in today's complex and fast-moving environment, much more than the technically competent 'administration' envisaged by Woodrow Wilson. It presupposed both 
transactional and at times transformational leadership aimed at institutionbuilding, stewardship, reform, networking, and alliance-formation (Selznick 1957; Lewis 1980; Terry 1995; Moore 1995; Boin 2001). Ironically, then, the emasculation of the old bureaucratic leadership was accompanied by a much more pronounced emphasis on leadership throughout the entire service, so that centralization at the top was balanced by general dispersal of discretionary authority below. This dispersal of the leadership function throughout the whole service, however, created multiple sites (rather than the few that has previously existed) that might potentially evade the effective control of elected governments. After several decades of reform, and with an undoubted decline in professional expertise in many administrative spheres, it is not clear whether what we might term the de facto 'democratization' of the service has gone too far or not far enough (Kane and Patapan 2006).

\section{(p.309) The judiciary}

Judicial leaders sit on top of micro-political systems full of potentially recalcitrant professionals. Judges enjoy strong positional protection, and are traditionally inclined to jealously guard their professional autonomy against 'managerial' attempts by their institution's executives to tell them what to do or change the way they do things. But as Tushnet indicates, the real litmus test for judicial leadership is in managing its relations to the political system at large, particularly the executive and legislative branches of government.

The judiciary, like the bureaucracy, forms a site of authority which is partly complementary to and partly independent of elected authorities. Judicial leaders are more securely situated than bureaucratic ones because they can draw on the ancient authority of the law itself, and especially because liberal constitutionalism insists so strongly on the separation and independence of the judicial power. (The notable exception, as Tushnet points out, are those State judges in the United States who must be elected to office, and who thus have no real autonomy from the democratic political system.) Judicial power is considerable because liberal democracies exist under the rule of law, and judges get to determine authoritatively what laws mean. Though held to be strictly 'legal', their interpretations nevertheless implicate the judiciary in every area of policy - tax, business, regulation, land tenure, and so on. Of most political consequence, however, are the judges who sit atop a federal system with powers of constitutional interpretation. These can act as genuinely political leaders because they may make authoritative findings on matters of great social consequence that are very difficult or even impossible for elected governments to overrule or alter. This is inevitably a cause of considerable tension, controversy, and even anger. Judges will generally be very circumspect about how and when they exercise such power in a democratic system. Tushnet in his chapter identifies the external conditions that make such occasional forays into judicial political leadership possible. 
Because of the separation of powers, the real struggle over control versus autonomy in the judicial realm occurs in the process of appointments. Elected leaders who get to appoint judges to fill vacancies on important courts can have a political influence that long outlasts their tenure. Of course, control is hardly perfect here, for securely independent judges may judge in unanticipated ways, but a series of either 'conservative', 'liberal', or 'activist' appointments can certainly alter the tenor of the judiciary for many years to come.

\section{Civic leadership}

The civil society leaders who run community organizations are actively engaged in delivering services to those who need them, either in conjunction with - as

(p.310) contractor or partner - or as an alternative to government service provision. They would seem to represent, therefore, a paradigm case of democratic dispersal. But Schmid's chapter teaches us that the reality is more complicated. The drama of dispersal versus autonomy occurs in the sector because Non-profit Organization (NPO) leaders experience tension between engaging with their constituents as political activists and serving them as clients. Indeed, this dual function produces a certain strategic dilemma. The more passionately leaders perform advocacy and watchdog roles, the more likely they are to collide with government elites. As service providers, however, their dependency on government resources may incline them towards pragmatic cooperation. Yet to appear effectively co-opted erodes the aura of independent partisanship that forms the moral capital they need to be credible to followers. Large service-oriented NPOs tend to be strongly reliant on 'soft money'. They are more likely to be docile creatures of government than a locus of alternative leadership contributing to the public scrutiny of governments, certainly when compared to their more advocacy-oriented or philanthropy-funded counterparts.

In many ways, the same dilemma affects the university leaders described by Davis and Sharrock. Not only is their office not a product of democratic dispersal - universities antedate the spread of democracy by centuries - the very office itself entails a complex blend of executive power within their own micropolitical systems and civic duty in their roles as defenders of academic freedom and 'voice' in the larger democratic polity. Many university administrators within and beyond the United States wrestled with this tension during the political escalation of the Vietnam War: would they defend the students' rights to hold (large-scale, repeated) protest rallies against the US government's war policy, or would they use or invoke executive power to maintain order and minimize disruption on campus?

NPO and university leaders both wrestle with the civic leadership dilemma of purity versus pragmatism. Civic leaders may choose to 'deal with the devil' in order to do some tangible good', but at the risk of being seen to have 'sold out', losing their credibility as a result (Baraket 2008; Shergold 2008). As Davis and Sharrock argue, civic leaders need courage, one way or the other: the courage 
to assert academic autonomy when governments of the day seek to curtail it, but also the courage to 'do deals' with government and/or business in the face of purist opposition within their own ranks.

\section{Assessing leadership dispersal}

Granted that dispersed leadership is an inevitable consequence of liberal democratic development, we might nevertheless inquire what its value is for democratic government. Is dispersed leadership, in short, actually good for democracy, and does it make governance 'more democratic'? The answer (p. 311) we give to such questions will depend on the normative yardstick we use to judge, and it should be evident from all that has been said above that no single agreed yardstick is possible. We have argued that dispersal occurs both under the force of the principle of popular sovereignty and under that of liberal constitutionalism; the quality of a government will be differently judged depending on which of these is used as the relevant yardstick. Moreover, we have seen that dispersal, however motivated, causes recurrent tensions and contests over ultimate control of political agendas. These are all, in the end, struggles to achieve coherent government by resisting the natural fragmentation of democracy, thus providing a third yardstick, effectiveness. We thus arrive at three normative bases for assessing the effects of dispersal, as identified by Bovens, 't Hart, and Schillemans (2008): popular control; checks and balances; and effective governance. Leadership is important in all three, but each has different concerns about leadership in democracy: accountability, harm minimization, and effectiveness, respectively (see Table 16.1).

First, the idea of popular control has been theoretically defined, in contemporary terminology, on the principal-agent model. According to this, a modern representative democracy can be described as a concatenation of principalagent relationships (Strom 2000, 2003; Lupia 2003). The people (the primary principals in a democracy) have delegated their authority to popular representatives, who, in turn, have delegated the drafting and enforcement of laws and policy to the government. Ministers subsequently entrust policy implementation to their ministries, who proceed to delegate parts of these

\section{Table 16.1 Evaluating democratic leadership: three perspectives}

\begin{tabular}{llll} 
& $\begin{array}{l}\text { Democratic } \\
\text { responsiveness }\end{array}$ & $\begin{array}{l}\text { Democratic } \\
\text { constitutionalism }\end{array}$ & $\begin{array}{l}\text { Democratic } \\
\text { resilience }\end{array}$ \\
\hline $\begin{array}{l}\text { Key } \\
\text { criterion }\end{array}$ & Leaders to be recruited & Leaders' power to be & $\begin{array}{l}\text { Leaders to be } \\
\text { and sensitized to }\end{array}$ \\
serving citizens & checked by & $\begin{array}{l}\text { induced to } \\
\text { communicate, }\end{array}$ \\
& & reflect, and \\
& & collaborate
\end{tabular}




\begin{tabular}{|c|c|c|c|}
\hline & $\begin{array}{l}\text { Democratic } \\
\text { responsiveness }\end{array}$ & $\begin{array}{l}\text { Democratic } \\
\text { constitutionalism }\end{array}$ & $\begin{array}{l}\text { Democratic } \\
\text { resilience }\end{array}$ \\
\hline \multirow[t]{2}{*}{ Favours } & $\begin{array}{l}\text { Representation as key } \\
\text { design principle for all } \\
\text { public offices (leader } \\
\text { recruitment as well as } \\
\text { office-holding } \\
\text { practices) }\end{array}$ & $\begin{array}{l}\text { Independent, strong } \\
\text { civic 'voice', and } \\
\text { judicial } \\
\text { 'accountability' } \\
\text { forums and leaders }\end{array}$ & $\begin{array}{l}\text { Variety and overlap } \\
\text { in public } \\
\text { leadership offices, } \\
\text { and strong } \\
\text { inducements to } \\
\text { leader reflexivity } \\
\text { and dialogue }\end{array}$ \\
\hline & $\begin{array}{l}\text { Representative } \\
\text { democracy }\end{array}$ & Monitory democracy & $\begin{array}{l}\text { Deliberative } \\
\text { democracy }\end{array}$ \\
\hline Fears & $\begin{array}{l}\text { Preponderance of } \\
\text { 'technocratic' (e.g. } \\
\text { administrative and } \\
\text { judicial) over } \\
\text { 'democratic' (e.g. } \\
\text { political and civic) } \\
\text { leadership forms }\end{array}$ & $\begin{array}{l}\text { Executive (political } \\
\text { and administrative) } \\
\text { capacity to escape } \\
\text { independent scrutiny } \\
\text { and/or avoid sanction } \\
\text { of past performance }\end{array}$ & $\begin{array}{l}\text { Weak civil } \\
\text { societies; } \\
\text { homogeneous elite } \\
\text { recruitment and } \\
\text { socialization } \\
\text { practices; } \\
\text { charismatic and } \\
\text { other forms of } \\
\text { strong and 'greedy' } \\
\text { leadership }\end{array}$ \\
\hline & Technocracy & $\begin{array}{l}\text { Oligarchic } \\
\text { authoritarianism }\end{array}$ & $\begin{array}{l}\text { Plebiscitary, } \\
\text { charismatic rule }\end{array}$ \\
\hline
\end{tabular}

(p.312) tasks to more or less independent bodies and institutions. Public servants at the end of this chain of delegation end up spending billions in taxpayers' money and using their discretionary powers to furnish licences and subsidies, distribute benefits, impose fines, prosecute people, and a host of other tasks. Each set of leadersprincipals in the chain of delegation seeks to monitor the execution of the delegated public tasks by calling the agent-leaders to account. At the end of the chain are the citizens, who pass judgement on the conduct of leaders and who indicate their pleasure or displeasure at election times.

Of prime importance to effective accountability are all the organs of the modern media, one of whose tasks is to investigate, expose, and judge all the acts of government. The aim of this whole system of accountability is to ensure that the leadership is kept as closely as possible in touch with the sovereign people's expressed wishes. In other words, this criterion for judging the value of democratic dispersal is primarily concerned with the democratic responsiveness of leaders (Przeworski, Stokes, and Manin 1999). Leadership dispersal that improves responsiveness is, by definition, good. Dispersal that does not may or may not be good for other purposes but that is irrelevant to this perspective. 
The second set of criteria derives from the liberal idea of checks and balances. As we have seen, liberal constitutionalism is concerned with preventing tyrannous behaviour by leaders that would inevitably infringe individual rights. The main remedy against dangerously overbearing or improper government is the institutionalization of countervailing powers. Other public institutions, such as an independent judicial power, special tribunals, legislative committees, and so on act as complementary political watchdogs. There are, indeed, a whole host of such monitory institutions and forms not covered in this volume - Freedom of Information provisions; audit offices; Ombudsmen; an entire wave (some call it an 'explosion') of 'horizontal' accountability mechanisms (Power 1994) - that give citizens opportunities to hold to account actors and networks exercising discretionary administrative power (Bovens 2007; Bovens et al. 2008).

Under this liberal model, power is granted to leaders but the prime concern is to constitutionalize power, which means to keep it securely in check. This criterion of judgement therefore earns the label democratic constitutionalism. Dispersal that improves checking ability is good, by definition. As in the previous case, other forms of dispersed leadership may be good after their fashion but of no moment under this perspective.

The third perspective is that of effective governance. It is concerned with actually getting useful or necessary things done. Though leaders may often feel this requires rising above or even silencing the democratic cacophony, taking effective power into a single set of hands, democracies inevitably resist such attempts sooner or later. Leadership dispersal might be seen as beneficial from an effectiveness perspective, however, if it contributes to what Lindblom (p. 313) (1965) called 'the intelligence of democracy': that is, the capacity to arrive at appropriate solutions to complex predicaments and to adapt to changing circumstances. Defenders of this view argue that leadership structures and processes should facilitate this key aim, an achievement that depends on maintaining and strengthening leadership learning capacity (van der Berg 1999: 40; Aucoin and Heintzman 2000: 52-4). Leaders' awareness that they inhabit a world in which many others play crucial public leadership roles serves, it is argued, to focus their minds and stop them becoming inward looking ('t Veld, Schaap, Termeer, and van Twist 1991). They are forced to consider feedback about their own performance (Behn 2001) and to genuinely communicate with 'outside actors' (O'Loughlin 1990). The public nature of the dialogue between overlapping and competing leaders teaches all what is expected, what works and what does not.

There is a public accountability aspect to this criterion of judging dispersal that emphasizes responsiveness, but the mechanisms involved are less adversarial than 'exhortative'. The prime concern is with democratic resilience. It is not, in 
other words, about 'keeping them honest' but about keeping them smart and sharp.

Thus weighing the pros and cons of dispersal from each different perspective, we may arrive at quite different judgements as to value, as noted in Table 16.1. These criteria, though distinct, are not mutually exclusive, in the sense that it is quite possible for citizens to want responsiveness and checking and effectiveness. Yet having more of one may easily mean having less of another, forcing people to prioritize. For example, the proliferation of public accountability arrangements in many democracies may be warmly embraced by proponents of democratic constitutionalism who welcome the trend towards 'monitory democracy' (Keane 2009). Defenders of a democratic responsiveness perspective would be concerned to maintain a balance between democratic and liberal constitutional forms of accountability arrangements; many of the new checking mechanisms are of a purely technocratic kind and do not necessarily keep public leaders attuned to the needs of clients and stakeholders in society at large. Proponents of the democratic resilience perspective, however, may argue that more accountability is 'too much of a good thing', pointing to the risk of accountability overload and overzealous behaviour by public watchdogs. Indeed, critical accounts of the growing size, prominence and complexity of the transparency and accountability 'industry' (overview in Bovens et al. 2008) argue that too many watchdogs render the system M.A.D. (suffering from 'Multiple Accountabilities Disorder', see Koppell 2005).

As another example, consider the trend towards 'presidentialization' discussed above. From a democratic responsiveness perspective, this may be judged the self-assertion of a democratically elected leader embodying the popular will who is concerned to counter the creeping technocratic rule of shadowy administrators. Democratic constitutionalists may take a bleaker (p.314) view, seeing presidentialization as a new manifestation of oligarchic tendencies that threaten to shred the carefully woven web of accountabilities (Körösényi 2005, 2007; Higley and Pakulski 2008). Finally, those judging from a democratic resilience perspective might note that cosy cliques built around dominant leaders have a tendency to develop a distorted picture of reality, indulging in Groupthink and leaving prudence and responsibility by the wayside. Recent examples in the United Kingdom and the United States have reconfirmed what we have known for a long time: that when crucial decisions about complex and controversial matters are made by narrowly composed 'inner circles' to the exclusion of relevant stakeholders, expert analysis, and public accountability, policy fiascos result ('t Hart 1994).

We may conclude, therefore, that the question of whether greater dispersal is a good or a bad thing for a democracy is too simplistic. It all depends. Obviously the question of balance is critical here. Concentrating power may seem superficially more efficient and effective, but the dangers of concentration are 
not figments of liberal democratic imagination. Successful liberal democracies attempt to occupy a difficult middle ground between excessive concentration and excessive fragmentation of authority, with sufficient channels that connect leaders meaningfully to citizens, sufficient mechanisms for checking and balancing, and sufficient flexibility and intelligence to provide genuinely good governance. Of course, this moderate position is easier to state than to achieve, especially in a system as dynamic as a democratic one. It is often difficult to judge new developments when one is in the midst of them, yet it is wise to keep the ideal of balance always before one's mind.

Implications for the study of democratic leadership Contemporary studies of leadership in democracy tend to be dominated by political psychologists on the one hand, and students of executive government on the other. Looking at leadership in democracy through the lens of dispersal offers several key advantages over these. First, it helps us move away from a narrow preoccupation with leadership in the executive branch, and in particular with heads of government. Many public leaders help shape debate and policy in a democracy, and it is helpful to balance a person-centred approach with more contextual, institutional, and relational approaches to leadership analysis. We are rewarded with a surer grasp of the manifold ways in which leaders and leadership operate in democratic societies.

Second, our examination of dispersed democratic leadership brings to light important and contending notions regarding the merits of such dispersion and its implications for democratic governance. In allowing us to see more clearly the different expectations at stake, we are better placed to understand (p.315) and appraise the extraordinary opportunities as well as onerous demands placed on leaders in democracies.

Third, the focus on dispersal allows us to explore the extraordinary range of offices made possible in democracies. In addition to the variety of office, this research reveals the extent to which each office is itself subject to the demands of democratic leadership - to ensure accountability, inclusion, indeed dispersal of authority, while attempting to retain important features of coherent, efficient and technically sound and professional leadership.

Fourth, dispersal reveals that public office-holding is neither a necessary nor a sufficient condition for exercising public leadership. The Hargrove, Uhr, Sykes, Verbeek, and Tushnet chapters all provide ample illustrations of this proposition. Only a subset of the presidents, prime ministers, opposition leaders, women ministers, IGO leaders, and court presidents covered in their accounts has been widely understood to have managed to utilize their offices to exercise effective leadership, that is, to perform one or several of the key leadership roles distinguished in Table 1.1 in non-trivial and widely supported ways. Some officeholders simply lack the appropriate skills (Greenstein 2000; Lord 2003; Keohane 
2005) or luck (Dowding 2008). Others end up being short of political momentum (Skowronek 2008), time in office (Bynander and 't Hart 2007), or situational opportunities (Boin, 't Hart, Stern, and Sundelius 2005; Boin, 't Hart, and McConnell 2009) to actively lead and bring their followers and non-followers along. In contrast, consider Pim Fortuyn's brief but paradigm-shattering political ascendancy, the post-presidency peacemaking of Jimmy Carter, or Oprah Winfrey's political kingmaking. These and the many other examples discussed in this volume by de Beus, Keane, and 't Hart and Tindall illustrate the leadership potential of individuals who do not hold public office but nevertheless possess many or all of the above leadership resources.

Vibrant civil societies provide democracies with a rich mosaic of non-officebased public leadership: watchdogs, moralists, dissidents, clergy, revolutionaries, and social entrepreneurs. Some rely on personal charisma to build momentous social movements, others effectively exploit the moral capital of already established non-government institutions to perform civic leadership work. Some work alongside existing office-holders and regimes, others in stark opposition to them. Some self-consciously craft a public persona in the limelight of democratic deliberation and political controversy; others self-effacingly accomplish significant feats of public service unseen by the larger public but keenly welcomed by beneficiaries and followers (Barker, Johnson, and Lavalette 2001; Kane 2001; Elkington and Hartigan 2008; Kane, Patapan, and Wong 2008).

Future research

Future studies of leadership dispersal need to deepen our understanding of how democracies reconcile the challenge of dispersal of office and authority (p.316) with the demands of stability, efficiency, and accountability; how such accommodation evolves under different systemic and situational conditions; and how different office-holders perceive and tackle it. In particular, we suggest three avenues for further research. First, we need studies examining the way democracies appear to manage the formidable centrifugal and centripetal leadership forces that shape contemporary politics (Wren 2007; Gerring and Thacker 2008). Given the powerful tendency to dispersal, the sheer number of leadership loci and the potentially deeply conflictual relationships between them, how do democracies manage to combine and safeguard responsiveness, resilience, and constitutionalism? When and why do they fail to do so? We need to infuse the comparative analysis of democratic transition, consolidation, and possible breakdown (as pursued by scholars like Linz and Stepan 1978, 1996), as well as the normative study of democratic design - even its leadershipeschewing strand of deliberative democracy - with a more explicit and certainly more sophisticated leadership perspective that takes into account the importance of democratic dispersal of office. Such an approach has the potential to contribute new insights into the study of democratic theory, democratization, and constitutionalism. 
Second, we need to re-balance the study of leadership in political science, which is currently dominated by a preoccupation with executive government leaders (presidents, prime ministers, and senior bureaucrats). Whilst not abandoning this endeavour, a supplementary research programme should focus on the nature, forms, and implications of leadership that goes beyond these forms to include an ever-expanding range of non-executive- and non-office-based leadership. Democratic polities around the world have been experimenting with institutional innovation (decentralization, delegation, democratization, and internationalization). In the process, many new structures and opportunities for public leadership have been created: new venues for agenda-setting, policy design, authoritative choice, service delivery, and conflict management. From a democratic leadership perspective, future research needs to track these developments and map these changes. What are these venues? How if at all are leadership roles institutionalized within them? Which informal leadership practices develop in and around them, and how can these be assessed from the perspective of democratic responsiveness, constitutionalism, and resilience?

Finally, the dispersal perspective affects our notions of good and bad leadership. Existing research tends to evaluate leadership in terms of the performance of individual office-holders, exemplified by the apparent irresistibility of efforts to assess presidential or prime-ministerial 'success' or even 'greatness' (Simonton 1987; Greenstein 2000; Landy and Milkis 2000; Theakston and Gill 2006; Theakston 2007; Cozma 2008). Quite aside from the immanent critique such efforts may elicit, we suggest that at the very least they need to be supplemented by studies looking at leadership success as a feature of institutional design at the level of the polity. The nature and scope of the office inevitably (p.317) empowers and constrains leaders. As such it defines the moral potential of leadership. A focus on dispersal of democratic office corrects the tendency to impose strict moral codes and templates on leaders, providing an important contextual flexibility in judgement that takes into account the ethical potential of office and institutions and therefore a more nuanced appreciation of the moral dimension of political leadership. It makes possible a new approach to the understanding of moral leadership.

These three new avenues of research are intended to be no more than an indication of the range of possibilities opened up by the notion of dispersed leadership - the list can easily be expanded. Yet all such approaches will inevitably confront and address a core democratic challenge. Democracies give voice and power to a wide range of people and offices. How they manage to reconcile this dispersal with high expectations of accountability, efficiency, and transparency remains the continuing challenge of dispersed democratic leadership.

Bibliography 
Bibliography references:

Agranoff, R., Managing Within Networks: Adding Value to Public Organizations (Washington: Georgetown University Press, 2007).

Argyris, C. and Schon, D., Organisational Learning: A Theory of Action Perspective (Reading, Mass.: Addison Wesley, 1978).

Aucoin, P. and Heintzman, R., 'The Dialectics of Accountability for Performance in Public Management Reform', International Review of Administrative Sciences, 66 (2000), 45-55.

Bagehot, W., The English Constitution, 2nd edn., (1873), available at: 〈http:// socserv.mcmaster.ca/econ/ugcm/3ll3/bagehot/constitution.pdf).

Baraket, J. (ed.), Strategic Issues in the Non-Profit Sector (Sydney: University of New South Wales Press, 2008).

Barber, B., Strong Democracy (Berkeley, CA: University of California Press, 1984).

Barker, C., Johnson, A., and Lavalette, M. (eds.), Leadership and Social Movements (Manchester: Manchester University Press, 2001).

Bauman, Z., Liquid Modernity (Cambridge: Polity Press, 2000).

Behn, R., Rethinking Democratic Accountability (Washington, DC: Brookings Institution Press, 2001).

Bendor, J., Parallel Systems: Redundancy in Government (Berkeley, CA: University of California Press, 1985).

Benhabib, S. (ed.), Democracy and Difference: Contesting the Boundaries of the Political (Princeton, New Jersey: Princeton University Press, 1996).

Berg, J. van der, Verantwoorden of Vertrekken: Een Essay over Politieke Verantwoordelijkheid (The Hague: VNG uitgeverij, 1999).

Boin, A., Crafting Public Institutions: Leadership in Two Prison Systems (Boulder, Col.: Lynne Rienner Publishers, 2001).

and Goodin, R. E., 'Institutionalizing Upstarts: The Demons of Domestication and the Benefits of Recalcitrance', Acta Politica, 42/1 (2007), 4057.

(p.318) Boin, A., 't Hart, P., and McConnell, A., 'Crisis Exploitation: Political and Policy Impacts of Framing Contests', Journal of European Public Policy, 16/1 (2009), 81-106. 
- - - - Stern, E., and Sundelius, B., The Politics Of Crisis Management: Public Leadership Under Pressure (Cambridge: Cambridge University Press, 2005).

Bovens, M., 'New Forms of Accountability and EU Governance', Comparative European Politics, 5/1 (2007), 104-20.

-_'t Hart, P., and Schillemans, T., 'Does Accountability Work? An Assessment Tool', Public Administration, 86/1 (2008), 225-42.

- - Derksen, W., Witteveen, W., Becker, F., and Kalma, P., De verplaatsing van de politiek; een agenda voor democratische vernieuwing (Amsterdam: Wiarda Beckmanstichting, 1995).

Braithwaite, J., 'On Speaking Softly and Carrying Big Sticks: Neglected Dimensions of a Republican Separation of Powers', University of Toronto Law Journal, 47/3 (1997), 305-61.

Bynander, F. and 't Hart, P., 'The Politics of Party Leader Survival and Succession: Australia in Comparative Perspective', Australian Journal of Political Science, 42/1 (2007), 47-72.

Cohen, J., 'The Economic Basis of Deliberative Democracy', Social Philosophy and Policy, 6/2 Spring (1989), 25-50.

Cozma, R., 'Presidential Greatness Reconsidered: How Modern Great Presidents Differ From The Old Ones In Terms Of Leadership Style', Paper presented at the annual meeting of The ISA's 49th Annual Convention, Bridging Multiple Divides, San Francisco, San Francisco, California, 26 March 2008, available at: 〈http:// www.allacademic.com/meta/p252080_index.html).

Crosby, B. and Bryson, J. D., Leadership for the Common Good: Tackling Public Problems in a Shared Power World, 2nd edn. (San Francisco, CA: Jossey Bass, 2005).

Cunningham, S., 'Political and Media Leadership in the Age of YouTube', in P. 't Hart and J. Uhr (eds.), Public Leadership: Perspectives and Practices (Canberra: ANU E Press, 2008), 177-88.

Curtin, D. and Wille, A. (eds.), 'Meanings and Practice of Accountability in the EU Multi-Level Context’, Connex Report Series Vol. 7, Mannheim, 2008.

De Zwart, F., The Bureaucratic Merry-go-round: Manipulating the Transfer of Indian Civil Servants (Amsterdam: Amsterdam University Press, 1994).

Deutsch, K. W., The Nerves of Government (New York: The Free Press, 1963).

Dowding, K., 'Perceptions of Leadership', in P. 't Hart and J. Uhr (eds.), Public Leadership: Perspectives and Practices (Canberra: ANU E Press, 2008), 93-102. 
Draper, T., A Very Thin Line: The Iran-Contra Affairs (New York: Simon and Schuster, 1991).

Dror, Y., Policymaking under Adversity (New Brunswick: Transaction, 1986).

- - The Capacity to Govern: A Report to the Club of Rome 2002 (London and Portland, Oregon: Frank Cass, 2001).

Dryzek, J. S., Discursive Democracy: Politics, Policy and Political Science (New York: Cambridge University Press, 1990).

Elkington, J. and Hartington, P., Power of Unreasonable People: How Social Entrepreneurs Create Markets that Change the World (Cambridge, Mass.: Harvard Business School Press, 2008).

Fisher, E., 'The European Union in the Age of Accountability', Oxford Journal of Legal Studies, 24/1 (2004), 495-515.

(p.319) Foley, M., The Rise of the British Presidency (Manchester: Manchester University Press, 1993).

- - The British Presidency (Manchester: Manchester University Press, 2000).

Frissen, P., Politics, Governance, and Technology (Cheltenham: Elgar, 1999).

Gerring, J. and Thacker, S. C., A Centripetal Theory of Democratic Governance (Cambridge: Cambridge University Press, 2008).

Godechot, J., The Counter-Revolution: Doctrine and Action (Princeton, New Jersey: Princeton University Press, 1981).

Goldsmith, S. and Eggers, W. D., Governing by Network: The New Shape of the Public Sector (Washington, DC: Brookings Institute, 2004).

Goodin, R. E., 'Democratic Accountability: The Distinctiveness of the Third Sector', European Journal of Sociology, 44/3 (2003), 359-96.

Greenstein, F., The Presidential Difference: Leadership Style from FDR to Clinton (New York: Free Press, 2000).

Gutmann, F. and Thompson, D., Why Deliberative Democracy? (Princeton, New Jersey: Princeton University Press, 2004).

Higley, J. and Kapulski, J., 'Toward Leader Democracy', in P. 't Hart and J. Uha (eds.), Public Leadership Perspectives and Practices (Canberra, ANUE Press, 2008), 45-55. 
Huls, N., Adams, M., and Bomhoff, J. (eds.), The Legitimacy of Highest Courts' Rulings: Judicial Deliberations and Beyond (Cambridge: Cambridge University Press, 2009).

In't Veld, R., Schaap, E., Termeer, C., and van Twist, M. (eds.), Autopoiesis and Configuration Theory: New Approaches to Societal Steering (Dordrecht: Kluwer, 1991).

Kane, J., The Politics of Moral Capital (Cambridge: Cambridge University Press, 2001).

- - and Patapan, H., 'In Search of Prudence: The Hidden Problem of Managerial Reform', Public Administration Review, 66/5 (2006), 711-24.

_- _ - 'The Neglected Problem of Democratic Leadership', in P. 't Hart and J. Uhr, Public Leadership: Perspectives and Practices (Canberra: ANU E Press, 2008), 25-36.

- - - - and Wong, B., Dissident Democrats: The Challenge of Democratic Leadership in Asia (New York: Palgrave Macmillan, 2008).

Keane, J., The Life and Death of Democracy (London, New York and Madrid: Simon and Schuster, 2009).

Keohane, N., 'On Leadership', Perspectives on Politics, 3/4 (2005), 705-22.

Koppell, J., 'Pathologies of Accountability: ICANN and the Challenge of "Multiple Accountabilities Disorder" ', Public Administration Review, 65/1 (2005), 94-108.

Koppenjan, J. and Klijn, E.-H., Managing Uncertainties in Networks (London: Routledge, 2004).

Körösényi, A., 'Political Representation in Leader Democracy', Government and Opposition, 40/3 (2005), 358-78.

-_'Political Leadership: Between Guardianship and Classical Democracy', Paper presented at ECPR Workshop on 'Political Leadership: A Missing Element in Democratic Theory', Helsinki, Finland, 7-12 May 2007.

Landau, M., 'Redundancy, Rationality, and the Problem of Duplication and Overlap', Public Administration Review, 29 (1969), 346-58.

Landy, M. and Milkis, S. M., Presidential Greatness (Kansas: Kansas University Press, 2000).

Lewis, E., Public Entrepreneurship: Toward a Theory of Bureaucratic Power (Bloomington, Indiana: Indiana University Press, 1980). 
Lijphart, A., Patterns of Democracy (New Haven, Conn.: Yale University Press, 1999).

(p.320) Lindblom, C. E., The Intelligence of Democracy: Decision Making Through Mutual Adjustment (New York: Free Press, 1965).

Linz, J. J. and Stepan, A. K. (eds.), The Breakdown of Democratic Regimes (Baltimore, Maryland: Johns Hopkins University Press, 1978).

- - - Problems of Democratic Transition and Consolidation: Southern Europe, South America, and Post-Communist Europe (Baltimore, Maryland: Johns Hopkins University Press, 1996).

Lord, C., The Modern Prince: What Leaders Need to Know Now (New Haven, Conn.: Yale University Press, 2003).

Luhmann, N., Theorie der Verwaltungswissenschaft: Bestandsaufnahme und Entwurf (Köln-Berlin: Grote, 1966).

Lupia, A., 'Delegation and its Perils', in K. Strom, W. C. Müller, and T. Bergman (eds.), Delegation and Accountability in Parliamentary Democracies (Oxford: Oxford University Press, 2003), 33-54.

March, J. G. and Olsen, J. P., Democratic Governance (New York: Free Press, 1995).

Moore, M., Creating Public Value (Cambridge: Harvard University Press, 1995).

Morse, R. S. and Buss, T. F., 'The Transformation of Public Leadership', in R. S. Morse, T. F. Buss, C. M. Kinghorn (eds.), Transforming Public Leadership for the 21st Century (Armonk: M. E. Sharpe, 2007), 3-19.

Nathan, R. P., The Administrative Presidency (New York: John Wiley and Sons, 1983).

Needham, C., 'Brand Leaders: Clinton, Blair and the Limitations of the Permanent Campaign', Political Studies, 53/2 (2005), 343-61.

O'Donnell, G., 'Horizontal Accountability in New Democracies', in A. Schedler, L. Diamond, and M. Plattner (eds.), The Self-Restraining State: Power and Accountability in New Democracies (London: Lynne Rienner, 1999), 29-51.

O'Loughlin, M., 'What is Bureaucratic Accountability and How Can We Measure It?', Administration and Society, 22/3 (1990), 275-302.

OECD, Focus on Citizens: Public Engagement for Better Policy and Services (Paris: Organization for Economic Cooperation and Development, 2008). 
Pakulski, J. and Higley, J., 'Towards Leader Democracy', in P. 't Hart and J. Uhr, Public Leadership: Perspectives and Practices (Canberra: ANU E Press, 2008), 45-56.

Poguntke, T. and Webb, P. (eds.), The Presidentialization of Politics: A Comparative Study of Modern Democracies (Oxford: Oxford University Press, 2005).

Power, M., The Audit Explosion (London: Demos, 1994).

Przeworski, A., Stokes, S., and Manin, B. (eds.), Democracy, Accountability, and Representation (Cambridge: Cambridge University Press, 1999).

Rhodes, R. A. W., Understanding Governance: Policy Networks, Governance, Reflexivity and Accountability (Buckingham: Open University Press, 1997).

-_'Blair and Governance', in R. Koch and J. Dixon (eds.), Public Governance and Leadership (Wiesbaden: Deutscher Universitäts-Verlag, 2007), 95-116.

Rosenthal, U., 'Politics and Administration: Max Weber and the Quest for Democratic Order', in A. Kouzmin and N. Scott (eds.), Dynamics in Australian Public Management: Selected Essays (Melbourne: Macmillan, 1990), 392-408.

Ruscio, K. P., The Leadership Dilemma in Modern Democracy (Cheltenham: Edward Elgar, 2004).

Schlesinger, A. M., The Imperial Presidency (Boston: Mariner Books, [1973] 2004).

Selznick, P., Leadership in Administration (New York: Harper and Row, 1957).

(p.321) Shergold, P., Dealing with Governments: The View from the Not-forProfit Sector (Sydney: Australian and New Zealand School of Government, 2008), unpublished speech.

Simonton, D. K., Why Presidents Succeed: A Political Psychology of Leadership (New Haven, Conn.: Yale University Press, 1987).

Skowronek, S., Presidential Leadership in Political Time: Reprise and Reappraisal (Lawrence, Kansas: University Press of Kansas, 2008).

Strom, K., 'Delegation and Accountability in Parliamentary Democracies', European Journal of Political Research, 37/3 (2000), 261-89.

-_ 'Parliamentary Democracy and Delegation', in K. Strom, W. Müller, and T. Bergman (eds.), Delegation and Accountability in Parliamentary Democracies (Oxford: Oxford University Press, 2003), 55-106. 
Terry, L. D., Leadership of Public Bureaucracies: The Administrator as Conservator (Thousand Oaks, CA: Sage, 1995).

't Hart, P., Groupthink in Government: A Study of Small Groups and Policy Failure (Baltimore, Maryland: Johns Hopkins University Press, 1994).

Theakston, K., 'What Makes for an Effective British Prime Minister?', Quaderni di scienza politica, 14 (2007), 39-61.

- - and Gill, M., 'Rating 20th-Century British Prime Ministers', The British Journal of Politics and International Relations, 8/2 (2006), 193-213.

Thompson, M., Ellis, R., and Wildavsky, A., Cultural Theory (Boulder, Col.: Westview, 1990).

Uhr, J., 'Distributed Authority in a Democracy: The Lattice of Leadership Revisited', in P. 't Hart and J. Uhr, Public Leadership: Perspectives and Practices (Canberra: ANU E Press, 2008), 37-44.

Walter, J. and Strangio, P., No, Prime Minister: Reclaiming Politics from Leaders (Sydney: University of New South Wales Press, 2007).

Willard, C. A., Liberalism and the Problem of Knowledge: A New Rhetoric for Modern Democracy (Chicago, Illinois: Chicago University Press, 1996).

Witteveen, W., Evenwicht van machten (Zwolle: Tjeenk Willink, 1991).

Wren, J. T., Inventing Leadership: The Challenge of Democracy (Cheltenham: Elgar, 2007). (p.322)

\section{Access brought to you by:}

